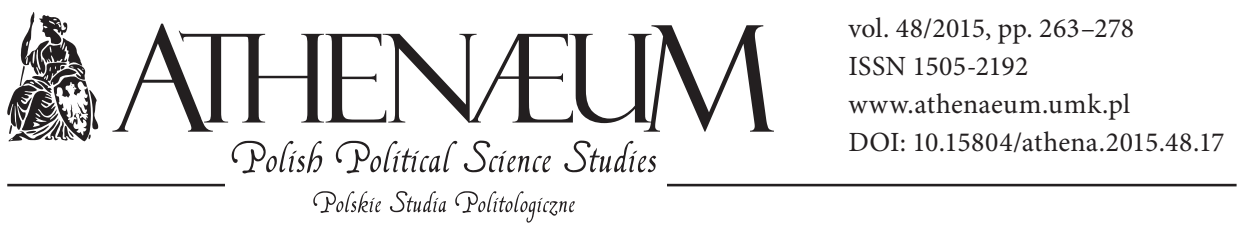

\title{
PROVISIONAL GOVERNING COUNCIL AS PART OF THE IMPACT OF STATE AUTHORITIES ON THE FUNCTIONING OF THE POLISH AUTOCEPHALOUS ORTHODOX CHURCH (1948-1951)
}

Stefan Dudra*

\begin{abstract}
On April 26, 1948, the Provisional Governing Council of PAKP was formed on the basis of minister of public administration Edward OsóbkaMorawski's directive. The decision was a consequence of the removal of Metropolitan Dionizy (Waledyński) from his position as the head of the Orthodox Church. It left the de facto function of the board of trustees in charge of the Orthodox Church. Provisional Governing Council had de facto the function of the receivership management in charge of the Orthodox Church. It took over all matters and documents of the Warsaw Orthodox Theological Consistory and the entire property of the Church in Poland. The state authorities appointed the Provisional Governing Council two main tasks to solve. They concerned: the problem of autocephaly and election of a new superior. The Council was also to solve the problem of deposed Metropolitan Dionizy (the expulsion outside Warsaw) and the reorganization of the administrative structure of the Church. Until July 1951, these tasks were completed.
\end{abstract}

\section{- KEYWORDS}

Orthodox Church, Council of Bishops, Provisional Governing Council

* University of Zielona Góra, Institute of Political Science. 


\section{INTRODUCTION}

On April 26 ${ }^{\text {th }}, 1948$ Provisional Governing Council of Polish Autocephalous Orthodox Church (PAKP) was formed on the basis of minister of public administration Edward Osóbka-Morawski's directive. The decision was a consequence of the removal of Metropolitan Dionizy (Waledyński) from his position as the head of the Orthodox Church ${ }^{1}$. The national authorities entrusted the chairman of the council to Archbishop Tymoteusz (Szretter). Moreover, there were appointed as members: Bishop Jerzy (parish priest of Łódź) ${ }^{2}$, Father Jan Kowalenko (managing the diocese Warsaw), Father Eugeniusz Naumow (parish priest of Gdańsk), Father Wsiewołod Łopuchowicz (metropolitan cathedral vicar), Father Michał Kiedrow (administrator of the monastery in Jabłeczna), and Mikołaj Sieriebriannikow, as so called representative of the "secular factor" (M. Sieriebriannikow was at that time the president of the Russian Charity Association) (Urban 1996: 74-75). In some meetings Jarosław Demianczuk-Jurkiewicz (Director of the Department of Religious Affairs MAP) and Serafin Kiryłowicz and Kazimierz Szulc (counsel Department) participated as the representatives of the state authorities.

Provisional Governing Council had de facto the function of the receivership management in charge of the Orthodox Church. It took over all matters and documents of the Warsaw Orthodox Theological Consistory (WDKP) and the entire property of the Church in Poland. At the same time, a resolution to dissolve the Metropolitan Chancellery was adopted (in its place the Council Chancellery was created). Despite these decisions, WDKP continued its work. In the years 1948-1951, administrative system of dual power actually existed in the Orthodox Church.

It is worth noting that establishing of the Provisional Governing Council had no legal basis. This kind of institution was not stated neither in the Decree of the President of November $18^{\text {th }}, 1938$ on the Relation of the State to PAKP, nor

1 The removal of Metropolitan Dionizy was politically motivated. The authorities did not accept him as the superior of the Church (hierarch was accused of collaboration with the pre-war regime and the German occupiers). The dismissal of the Metropolitan was also the violation of existing normative acts (including Presidential Decree of November $18^{\text {th }}, 1938$ ) by national authorities.

${ }^{2}$ On June $18^{\text {th }}, 1948$, Provisional Governing Council gave Bishop Jerzy (Korenistow) the title of Bishop of Łódź, suffragan of Warsaw diocese, Archives of New Files (AAN), the Ministry of Public Administration (MAP) Protocol 3 of the Meeting of the Provisional Governing Council PAKP, June $18^{\text {th }}, 1948$. 
in the Internal Statute from December 1938. Institutions of this kind did not exist in other normative acts of the Second Republic. For this reason, the body was illegal and contrary to the pre-war regulations creating the legal position of the Orthodox Church (Urban 1996: 94; Matwiejuk 2007: 44-45). Not without reason, characterizing this body, Metropolitan Dionizy wrote that "it violated the established canonical and hierarchical order in the Church and in general complicated its canonical situation, making members of the Council the rapists of canons, usurping the rights belonging to the canon Metropolitan and violating the principle of hierarchical obedience"3.

It is difficult to say why the state authorities decided to create the Provisional Governing Council, and did not appoint Archbishop Tymoteusz as the Metropolitan, who they worked closely with in real. He acted as Deputy Metropolitan (from November $12^{\text {th }}, 1948$ to July 1951 and from December $9^{\text {th }}, 1959$ to May 1961) and Metropolitan (from May $5^{\text {th }}, 1961$ until May 20 th, 1962 ). Perhaps the receivership management was supposed to be a pattern which was supposed to be used in case of forced personnel changes in other churches and religious associations.

After World War II, the Soviet religious authorities, using the Moscow Patriarchate, began the process of subordination of the Orthodox Churches in the countries of Central and Eastern Europe in order to pursue their own religious policy. The favorable element was taking over power in the area by the communists, as well as the rivalry between the Moscow and Constantinople patriarchates for influence in the Orthodox world. After joining Estonia on March $9^{\text {th }}, 1945$, the Estonian Apostolic Orthodox Church (Patriarchate of Constantinople jurisdiction) was eliminated, and the parishes and the faithful were incorporated into the structure of the Russian Orthodox Church. A similar fate befell the Orthodox Church in Latvia.

In the second half of 1945, the Orthodox Church in Czechoslovakia was subordinated by the government decree to the Moscow Patriarchate, which formed the Exarchate in Prague headed by Archbishop Eleutherius (Vorontsov) ${ }^{4}$. The next step was to give autocephaly (December $9^{\text {th }}, 1951$ ) (Suvarsky 1982: 56-61). This act was not recognized by the Patriarchate of Constantinople, recognizing

3 Archives of Warsaw Orthodox Metropolis (AWOM), sign. R IV-2B 1144, The Metropolitan Dionizy's letter to the Minister of Public Administration on December $2^{\text {nd }}, 1948$.

${ }^{4}$ Yet in May 1945, at the diocesan meeting in Olomouc, the Orthodox faithful decided to ask the Serbian Orthodox Church to be covered by its jurisdiction. 
only the autonomy of the Church in Czechoslovakia, the subsidiary directly from it ${ }^{5}$.

A new personnel policy in the Orthodox Church was also led by the authorities in Romania. After the death of Patriarch Nicodemus (Munteanu), a strong opponent of communist rule, in 1948, the authorities influenced the choice of his successor. As a result of pressure on the hierarchy, Justinian (Marina) became the new patriarch. In autumn 1948, Exarch Stefan (Szokow) was also forced to resign from the office of superior of the Orthodox Church in Bulgaria (Parry 2007: 65-66; Ramet 1984: 194). The hierarch, also enjoying great authority and support of the faithful, was accused by some bishops of sympathizing with the UK and the US (similar allegations were put forward against Metropolitan Dionizy in Poland) (Antonova 2011: 78-81).

In the changed post-1945 political situation in Hungary, several Orthodox parishes belonging to the Serbian Orthodox Church and the Patriarchate of Constantinople turned to the Patriarch of Moscow Alexy II for adoption into the jurisdiction of the Russian Orthodox Church. At the beginning of 1949, the Provisional Management Board of the Hungarian Orthodox Parish was appointed. And on November $15^{\text {th }}, 1949$, Hungarian deanery was erected (Péter 1995: 19-20).

After 1945, in the so-called "satellite states", the Soviet authorities influenced filling the positions of superiors of local Orthodox Churches. They aimed to their subordination and full control. One also attempted to use their activities both in the domestic and international affairs (including the World Council of Churches) (Ławreszuk 2009; Curanović 2010).

This article aims to show the activities of the Provisional Governing Council in three main areas (obtaining autocephaly, removing Metropolitan Dionizy and the election of the new Superior of the Church), which were appointed by state authorities, to indicate that this appointment resulted from changes in the state policy towards the Orthodox Church and the desire to acquire full control of its activities. The main determinant was supposed to be the election of the superior, who would collaborate closely and realize the state religious office guidelines. Archival resources gathered in Archives Records in Warsaw, Archives of the

5 This fact contributed to the exacerbation of mutual relations between the patriarchates. Constantinople did not give the Church of the Czech Republic and Slovakia autocephaly until 1998 (see: Ławreszuk 2009: 288). 
Institute of National Remembrance, and Archive of the Warsaw Metropolitan Church were used in this study.

The years 1948-1951 were a difficult period for the functioning of the Orthodox Church in Poland. It was deprived of his superior, who enjoyed great authority among both the clergy and the faithful in the country, and among the Orthodox hierarchs in the world. Besides, important issues for the development and future of the Church (including the case of reorganization of the administrative structure, the training of staff) were still not resolved.

The state authorities appointed the Provisional Governing Council two main tasks to solve. They concerned: the problem of autocephaly and the election of a new superior. The Council was also to solve the problem of deposed Metropolitan Dionizy (the expulsion outside Warsaw) and the reorganization of the administrative structure of the Church. An important element was also managing the daily affairs of the Church and leading to a normalization of internal relations. In this last aspect, however, the main role was played by WDKP 6 .

The first meeting of the Provisional Governing Council was held on May $5^{\text {th }}$, 1948. During the session, the fact of withdrawal of recognition Metropolitan Dionizy as the superior of the Orthodox Church in Poland was acknowledged. Some doubts about the nature of canonical irregularities related to this issue were reported by Father Jan Kowalenko. They concerned the matter of informing the hierarchy of his revocation from his position. This was rather brutally commented by Jarosław Demiańczuk-Jurkiewicz, who stated that "[...] the matter of the Metropolitan's notice to withdraw the recognition by the Citizen President of R.P. is a secondary issue, which belongs to the Polish Government, which in its time will do this" ". The members of the council were also notified by Archbishop Tymoteusz about sending a letter to Patriarch Aleksy, whose aim was to establish the canonical communication with the Moscow Patriarchate ${ }^{8}$.

\footnotetext{
6 AAN, MAP, sign. 1043, The Decree on the Appointment of the Provisional Governing Council of the Polish Autocephalous Orthodox Church. On May 24 ${ }^{\text {th }}, 1948$, WDKP circular addressed to the clergy PAKP on the appointment of the Interim Governing College was also released.

7 AAN, MAP, sign. 1044, Protocol no. 1 of the Meeting of the Provisional Governing Council PAKP on May $5^{\text {th }}, 1948$.

8 AAN, MAP, sign. 1044.
} 


\section{THE CASE OF AUTOCEPHALY}

One of the tasks of the Council was to bring to the canonical ordering the issue of autocephaly. This matter was not difficult to solve, because it was supported by the Polish authorities. The Orthodox hierarchy was also aware of the need to re-obtain it from the Moscow Patriarchate. The last one was interested in changing the situation which had arisen in $1924^{\circ}$.

The removal of Metropolitan Dionizy opened the way to obtain autocephaly from Moscow ${ }^{10}$. On April 30 ${ }^{\text {th }}$, 1948, Archbishop Tymoteusz addressed a letter to Patriarch Aleksy "[...] with a sincere and favorable treatment of the desire of The Hierarchy and flock of the Polish Autocephalous Orthodox Church to establish relations with the Holy Russian Church and for appointment of a special audience for the delegation of our Church"11. The fact of sending the letter even before the first official meeting of the Provisional Governing Council (gathered on May $5^{\text {th }}$ ) testified about the priority of this issue. In the later part of the letter, Archbishop Tymoteusz asked for the appointment of the audience for a delegation of the Orthodox Church, whose task was to establish direct relations, to present the situation of the Orthodox Church in Poland and to "get the blessing of the Parent Russian Church"12.

9 The Orthodox Church in Poland received autocephaly from the Patriarchate of Constantinople in 1924. However, it was not recognized by the Moscow Patriarchate. Orthodoxy in its organizational structure has no central authority, which is characteristic of Catholicism. Its organization is based on autocephaly, meaning independence of individual Orthodox Churches. It manifests itself in a separate internal system, the independence of the Church hierarchy in the country from the hierarchy of the Church located in another country, the existence of separate legislation, and in preserving local customs and rites of the church. Autocephalous Church does not break with the dogmatic and canonical relationships with other Orthodox Churches, which together form the Universal Orthodox Church, and it recognizes the primacy of honor of the Patriarch of Constantinople (Zyzykin 1933; Znosko 1973).

10 It was confirmed in February 1947 by H. Świątkowski, who wrote in a special memorandum that the regulation of relations with the Moscow Patriarchate was not difficult: "It's more a personal matter than essential. There can be no accord with the Moscow patriarchy, and no agreement on autocephaly of the Polish Orthodox Church until it is headed by Metropolitan Dionysius, whose remaining at its current position is like a challenge for the Moscow Patriarchate", AAN, The Office for Religious Affairs (UdSW), sign. 131/391, The Memorial of H. Świątkowski "The Case of Polish Orthodox Church in Poland" on February $10^{\text {th }}, 1947$.

11 AAN, MAP, sign. 1043, The Archbishop Tymoteusz's Letter to Patriarch Aleksy on April 30 ${ }^{\text {th }}$, 1948.

12 Patriarch Aleksy initially set the date of receiving the delegations on June $2-5^{\text {th }}, 1948$, AAN, MAP, sign. 1043, The Letter from Patriarch Aleksy to Archbishop Tymoteusz on May $12^{\text {th }}, 1948$. 
During the meeting of May $11^{\text {th }}, 1948$, the delegation to Moscow was gathered. It was assumed that it would be comprised of five people ${ }^{13}$. The controversy aroused about the question of who of the hierarchs should stand on its head. In the opinion of Father E. Naumow it should be Bishop Jerzy (in his opinion, Archbishop Tymoteusz as head of the Church should send a delegation, and not take part in it). M. Sieriebriannikow had the opposite view. He argued that Archbishop Tymoteusz's participation would demonstrate greater prestige and authority of the entire delegation. It was finally decided that the delegation will include Archbishop Tymoteusz, priests: Michał Kiedrow, Wsiewołod Łopuchowicz and Eugeniusz Naumow, and M. Sieriebriannikow. At the next meeting of the Council, Father W. Łopuchowicz was replaced in the delegation by Bishop Jerzy, which was done at the request of Archbishop Tymoteusz ${ }^{14}$.

The official visit was held between June $19-27^{\text {th }}, 1948$. In the course of it, on June 22 2 , "The Act of Reunification of Polish Orthodox Church with the Russian Orthodox Church and Giving Autocephaly" was signed. In a statement of the church delegation, autocephaly in 1924 was acknowledged as non-canonical and invalid. At the same time, it was stated that the Orthodox Church could not maintain liturgical and prayer communication with Metropolitan Dionizy, being disconnected from the Parent Russian Orthodox Church. They also proclaimed to stop "prayerful communion with all the priests and faithful [...] who share Metropolitan Dionizy's error [recognition of his autocephaly of 1924 as canonical - S.D.] until they repent" ${ }^{15}$. In response to this statement, the resumption of canonical and liturgical communication with the Orthodox Church in Poland was done ${ }^{16}$. As pointed out by Ryszard Michalak (2014: 119), by establishing communication with the Patriarchate of Moscow, the Council received an additional (after the decision of MAP) legitimacy of its authority over the Polish Orthodox Church.

13 During the discussion, it was wondered whether members of the delegation would be only members of the Council or the people who did not belong to that body. Bishop George (he put forward the candidacy of Father W. Wieżański) and M. Sieriebriannikow opted for the latter solution. It was finally decided that the delegation should consist only of members of that body; AAN, MAP, Protocol no. 2 of the Meeting of the Provisional Governing Council PAKP on May $11^{\text {th }}, 1948$.

14 Protocols nos. 2 and 3 of the Meeting of the Provisional Governing Council PAKP on May $11^{\text {th }}$, 1948 , and on June $18^{\text {th }}, 1948$.

15 The report on the trip of the delegation PAKP and the text "Act of reunification..." is held in the AAN, MAP, sign. 1043.

16 The case of autocephaly, see: K. Urban (1993); M. Bendza (2006). 
On November $27^{\text {th }}, 1948$, during the meeting of the Provisional Governing Council the message from Patriarch Aleksy of confirmation of the autocephaly of Orthodox Church in Poland by the Council of Bishops of the Russian Orthodox Church was acknowledged ${ }^{17}$.

Receiving autocephaly was important both for the Church and the State. As Antoni Mironowicz (2005: 244) stated, it confirmed "[...] separateness of the inner life of the local Church, its hierarchy independence of foreign centers, and it allowed to maintain local customs and rituals, legislation and judiciary. In turn, for the state authorities autocephaly was an opportunity to self-arrangement of relations with the Orthodox Church, without the interference of external factors". At the same time, the relations with the Moscow Patriarchate were normalized. On the other hand, it is difficult to agree with the statement that since then, the actions of the Orthodox Church in Poland were derived from Polish-Soviet and the state-church relations in Poland and the USSR. Without a doubt, they tried to use PAKP on international fora (the struggle for peace and disarmament in the vision promoted by the USSR propaganda). The reality was far more complicated, as - for example - subsequent removal of Metropolitan Makary from management of the Orthodox Church in Poland (Źerelik 1996: $31)^{18}$. The issue of autocephaly of 1948 and the state of the mutual relationships was described aptly by Metropolitan Sawa (Hrycuniak), who stated that it was first and foremost a political process, and the Orthodox Church in Poland was deprived of choice. It must be kept in mind that the religious policy of the communist authorities sought to limit activities and take full control of churches and religious associations ${ }^{19}$.

\section{THE ISSUE OF METROPOLITAN DIONIZY}

After solving the case of autocephaly, Provisional Governing Council began to work on finding a place where Metropolitan Dionizy, who was removed from the management of the Church, would stay. This issue aroused much controversy among the members of the Council, who repeatedly dealt with it. In most cases,

\footnotetext{
17 AAN, MAP, sign. 1045, Protocol no. 7of the Meeting of the Provisional Governing Council PAKP on November $27^{\text {th }}, 1948$.

18 In 1957, Polish authorities began the process of removing Metropolitan Makary from the management of the Orthodox Church, which was finally completed at the end of 1959.

19 More about the post-war religious politics, see: R. Michalak (2014).
} 
they concerned the expulsion of the hierarchy outside Warsaw. At the request of Archbishop Tymoteusz (meeting on June $30^{\text {th }}, 1948$ ), they decided to ask the authorities to transfer the Metropolitan from the Metropolitan House in Warsaw and assign him a permanent place of residence. It was argued that the old age of the hierarchy required appropriate living conditions, which he was currently deprived of. They suggested his release from the house arrest and allowing him to stay at a designated place ${ }^{20}$.

The case of moving the Metropolitan also returned at the meeting held on November $12^{\text {th }}, 1948$. Father Eugeniusz Naumow pointed out on the need for displacement of the hierarchy out of Warsaw. At the next meeting (on November $\left.27^{\text {th }}, 1948\right)$, Fathers W. Łopuchowicz and E. Naumow were mandated to find an appropriate place for the permanent residence of the Metropolitan ${ }^{21}$. At the same time, Ministry of Public Administration suggested placing the hierarchy in Otwock, as it was a health resort where it was possible to rent or purchase the villa ${ }^{22}$. However, the Church authorities were opposed to such a solution. They were afraid that placing the hierarchy in the town near Warsaw could be not desirable "for the good of the Church". During the discussion there was also a proposal to place the Metropolitan in Orneta or Płock ${ }^{23}$.

It is worth noting that the view of the members of the Provisional Governing Council regarding leaving the Metropolitan of Warsaw was not uniform. Definitely, the government and part of the clergy with the Father Eugeniusz Naumow at the helm were in favor of such a solution. Bishop Michał expressed a different

20 AAN, MAP, sign. 1043, Protocol no. 4 of the Meeting of the Provisional Governing Council PAKP on June $30^{\text {th }}, 1948$. The Letter of the Provisional Governing Council PAKP to the Ministry of Public Administration on July $1^{\text {st }}, 1948$.

21 AAN, MAP, sign. 1044, Priest E. Naumow's Report Presented at the Meeting of the Provisional Governing Council PAKP on November $12^{\text {th }}, 1948$. Protocol no. 7 of the Meeting of the Provisional Governing Council PAKP on November $27^{\text {th }}, 1948$.

22 AAN, MAP, sign. 1044, The Memorandum from the Meeting of the Provisional Governing Council PAKP on November $27^{\text {th }}, 1948$. It is worth noting that in Otwock, the Metropolitan had his own villa purchased in the 1920s (it was the summer residence of the hierarchy). In 1946 it was sold to the Missionary Benedictine Sisters.

23 The proposal of Orneta was submitted by Father E. Naumow, who emphasized that the parish owned a house with a home chapel. Moreover, "the beautiful city has a good connection with Olsztyn and good climatic conditions". Fathers Łopuchowicz and Naumow were obliged to investigate on-site conditions in Orneta and Płock, and to submit a detailed report; AAN, MAP, sign. 1044, The Memorandum from the Meeting of the Provisional Governing Council PAKP on November $27^{\text {th }}, 1948$. 
view on this issue. He suggested leaving Metropolitan Dionizy in Warsaw (in the Metropolitan House), with separate rooms and a personal chapel ${ }^{24}$.

At the meeting on December $16^{\text {th }}, 1948$, the case of the Metropolitan residence was raised again. Previously authorized priests (Fathers W. Łopuchowicz and E. Naumow) did not supervise the indicated earlier towns Orneta and Płock within the prescribed period (December $15^{\text {th }}$ ). The Council re-appointed them to undertake this mission and further instructed to check housing conditions in Poznań and Kalisz. Eventually, it was decided that a permanent place of residence of Metropolitan Dionizy could not be located in Warsaw, as well as near the capital ${ }^{25}$.

On January $25^{\text {th }}, 1949$, Father W. Łopuchowicz submitted a report on staying in Płock. It was decided that in the building of the Orthodox parish in Płock there are suitable apartments for a possible residence of Metropolitan Dionizy and for his ministry (the hierarch was to have an entire floor of the parish house at his disposal). At the same time, the Council authorized Archbishop Tymoteusz to ask the state authorities to prepare the entire operation (the displacement of private tenants and allocation of the required amount of state funds to carry out the necessary repair ${ }^{26}$. For unknown reasons, the Metropolitan, however, was not transferred to Płock.

In connection with the dragging out of the issue of the expulsion of the Metropolitan, there were voices of speeding up the whole process. Among other things, at the meeting of the Council on March $16^{\text {th }}, 1949$, M. Sieriebriannikow indicated that in the last period, a "drastic situation" in connection with the person of Metropolitan Dionizy had been created in the Orthodox Church in Warsaw. He stressed that among the "Orthodox populations, especially among women, rumors are disseminated about some persecution and harassment, applicable to him, which the other bishops and members of the Council are

24 Father Naumow even claimed that leaving the hierarchy for permanent residence in the capital and permitting the celebration of worship in the Orthodox metropolitan home chapel will be perceived by the faithful as a situation compromising the Council. AAN, MAP, sign. 1043, E. Naumow's Report to the Director of Religious Beliefs at the Ministry of Public Administration on November $30^{\text {th }}, 1948$.

25 AAN, MAP, sign. 1045, Protocol no. 8 of the Meeting of the Provisional Governing Council PAKP on December $16^{\text {th }}, 1948$.

26 AAN, MAP, sign. 1044, Protocol no. 10 of the Meeting of the Provisional Governing Council PAKP on January $25^{\text {th }}, 1949$. 
allegedly involved [...]. This creates him a martyr, his followers gather at services celebrated by him at the home church. Therefore, among the faithful undesirable ferment is produced, which, if not interrupted instantly, may lead to unpleasant consequences"27. Given the above, the Council obliged Archbishop Tymoteusz to take as soon as possible appropriate steps towards the transfer of Metropolitan Dionizy from Warsaw.

It is worth noting that the removal of Metropolitan Dionizy from Warsaw was also important due to the forthcoming election of the new superior of the Church. In August 1949, the Council expressed concern that his presence in Warsaw and occupying the metropolitan rooms can become an obstacle to the normal conduct of elections ${ }^{28}$. In the absence of a decision of the church authorities, the issue of the Metropolitan was taken by the Office for Religious Affairs (UdSW), formed in April 1950. The metropolitan received a letter ordering him to settle in Łagów Lubuski in April 195029. However, the visitation of the future place of settlement made by Father Atanazy Semeniuk and the document prepared by him, entitled "report on the unsuitability of allocated buildings for the residence of the Metropolitan", postponed for nearly a year the deportation (Urban 2007: 19). The Metropolitan himself, realizing that he would have to leave Warsaw, suggested placing him in Krakow. Finally, the state authorities indicated Sosnowiec, justifying the choice with "the climate", which supposedly was good to the hierarch ${ }^{30}$. In order to prepare suitable premises, Fathers W. Łopuchowicz and A. Semeniuk were sent to Sosnowiec at the end of April 1950. The Metropolitan has received an order to leave Warsaw in May 1951. He was settled in the building on 90 Żymierskiego Street ${ }^{31}$.

27 AAN, MAP, Protocol no. 21 of the Meeting of the Provisional Governing Council PAKP on March $16^{\text {th }}, 1949$.

28 AAN, MAP, Protocol no. 16 of the Meeting of the Provisional Governing Council PAKP on August $23^{\text {rd }}, 1949$.

29 AAN, MAP, UdSW, sign. 9/27, W. Wolski's Letter to Metropolitan Dionizy on April 19 1950.

30 In fact, in a short distance from the Metropolitan's house in Sosnowiec there was steelworks Szopienice; more broadly about the last years of Metropolitan Dionizy's life, see: S. Dudra (2010).

31 The Institute of National Remembrance (IPN), Katowice Branch Office (Ka), sign. 02/48, The Memo on May $12^{\text {th }}, 1955$. Urban reports that the deportation was probably at the end of April or in early May 1951, see: K. Urban (2007: 20). 


\section{THE ELECTION OF A NEW METROPOLITAN}

In parallel with the case of finding a place where Metropolitan Dionizy, removed from the management of the Church, was to stay, the Provisional Governing Council together with the state authorities intensified their preparations for the election of a new Metropolitan. The latter wanted the new Archbishop to pursue a policy consistent with the Polish raison d'état. This matter was also consulted with the Soviet religious authorities. In June 1948, the counselor of the Polish Embassy in Moscow Janusz Zambrowicz discussed this issue repeatedly with the head of the IV European Department of the Ministry of Foreign Affairs W. Aleksandrow. During one of the meetings, Zambrowicz asked directly about the indication of the relevant hierarchy ${ }^{32}$.

At the beginning of 1949, the Religious Department of MAP described the "personal skills" of the future candidate for the position of the Metropolitan. It was decided that he should have the ability to reorganize the life of the Orthodox Church, authority among the clergy and followers, appropriate training and experience as a bishop, and knowledge of the Polish language and Polish citizenship. At the same time, they stressed that none of the members of the Council of Bishops PAKP has not fully corresponded to the above-mentioned requirements. Generally, the authorities did not have political reservations against any of the hierarchs, because in their opinion they were loyal-connected to the new sociopolitical reality.

In the absence of a suitable candidate, the matter of filling the Metropolitan vacancy was protracted. The state authorities suggested that just as after 1918, when Bishop Jerzy (Jaroszewski) was brought from Italy, similar steps should be taken to resolve the current personal crisis. They pointed to the Soviet Union, where several hierarchs, former Polish citizens, were present ${ }^{33}$. Finally, the concept was supported by the Ministry of Safety and the Office for Religious Affairs. In the opinion of the latter, the clergy from the Soviet Union gave, on the one hand, the guarantee of absolute loyalty, and on the other hand, close cooperation with the Moscow Patriarchate directing worldwide Orthodox Church policy in a large part of the local Orthodox Churches. In this case, they counted on the support of "precious" - from the point of view of Moscow's policy - initia-

32 AAN, MAP, sign. 1043, Memorandums from the Talks between J. Zambrowicz and the Head of the IV European Department MID W. Aleksandrow from $17^{\text {th }}$ to $29^{\text {th }}$ June 1948.

33 AAN, MAP, UdSW, sign. 9/6, Memorandum from 1949. 
tives (including peace matters). It was hoped that the voice of the Orthodox Churches would reach the influential, opinion-forming Christian communities in the world. Basically, in international forum, PAKP, as well as other Orthodox Churches of the socialist countries, were to support the position and demands of the Moscow Patriarchate ${ }^{34}$. The latter was also interested in controlling the situation in the local episcopates. An important factor was also the reevaluation in the Polish state policy, the Stalinist system being shaped especially after 1948/1949, as well as a strong position and influence of the Soviet Union.

As a result of the adopted political arrangements, members of the Council of Bishops PAKP at its meeting on April 19 ${ }^{\text {th }}, 1951$, requested of the Moscow Patriarchate that they give a clergy person an ecclesiastical canon law permit to move into the jurisdiction of the Orthodox Church in Poland. The adoption of the above resolution was preceded by numerous consultations with the Office for Religious Affairs, which all the details had been agreed with (including the composition, timing, and funding of church delegations traveling) ${ }^{35}$.

The case of the head of Orthodox Church in Poland was positively concluded during the visit of representatives of the Moscow Orthodox Church (June 13-20 $0^{\text {th }}$ ). On June $15^{\text {th }}$, the Synod of the Russian Orthodox Church passed Archbishop of Lviv and Ternopil Makary (Oksijuk) on PAKP jurisdiction ${ }^{36}$. His choice was primarily due to finish the case of filling the Metropolitan throne and give a guarantee of loyalty to the Polish and Soviet authorities. They also counted on the involvement of the hierarch in missionary action among the Greek Catholics (he was very active in the action of liquidation of the Ukrainian Greek Catholic Church through the inclusion of its parishes into the Russian Orthodox Church).

34 The use of PAKP on the international forum was escalated only in the $60 \mathrm{~s}$. The plan was even to appoint the office of suffragan bishop at the Metropolitan office, coordinating foreign operations, and to develop a program of activity on the international forum; AIPN BU 01283/1653, Information Referring to the Current Situation in the Polish Autocephalous Orthodox Church on December $28^{\text {th }}$, 1963.

35 AAN, UdSW, sign. 9/6, The Memorandum on the Meeting with Archbishop Tymoteusz on April $7^{\text {th }}, 1951$.

36 Archbishop Makary (1884-1961) was born in Łukowisko (a village near Międzyrzecz Podlaski), graduated from Theological Seminary in Chełm and Theological Academy in Kiev, where he earned a doctorate in theology (1914). He taught, among others, at the University of Kiev. In 1942, he was ordained a priest and made vows, serving at the same time a pastoral ministry in Kiev parishes. In 1945, he received bishop's chirotonia and was appointed to the diocese of Lviv-Ternopil, see: D. Sawicki (2011: 10-11). 
Formalities of filling of the Metropolitan Cathedral were completed in early July 1951, after the arrival of Archbishop Makary to Warsaw. On July $6^{\text {th }}$, the Council of Bishops passed a resolution to accept Archbishop Makary to PAKP jurisdiction. A day later, he was elected as "the Metropolitan of Warsaw and the whole Poland". Thus, the next task given to the Provisional Governing Council by religious authorities was positively resolved.

\section{SUMMARY}

The Provisional Governing Council, in addition to the above themes, undertook a number of other issues important for the functioning of the Church (including the matter of Orthodox churches retained by the Roman Catholic Church). They also dealt with the budget, which a special committee (comprised of the Bishop Michał, Father W. Łopuchowicz, and M. Sieriebriannikow) was appointed to prepare. The agenda included also dealing with the property of Orthodox Church left in abandon ed parishes as a result of resettlement as part of the "Wisła" action (it concerned provinces of Kraków, Lublin, and Rzeszów). In this case, it was, among others, the decisions to ban the sale of sacred objects (only the possibility of their lease was allowed) $)^{37}$.

Despite functioning of the Provisional Governing Council, Warsaw Orthodox Clergy Consistory continues to operate; it was not liquidated until December 1951. In December 1948, the Council of Bishops resumed its activities. It was led by Archbishop Tymoteusz, who had been the deputy Metropolitan already since November $12^{\text {th }}$. In addition, the Metropolitan law office started to work on April $1^{\text {st }}, 1949^{38}$. Essentially, these institutions were duplicated partially within the scope of the administrative and ecclesiastical activities, which created, in many cases, the state of chaos and disorganization (e.g. in terms of filling the pastoral centers in western and northern Poland).

In four years, the main tasks given to the Provisional Governing Council by the state authorities had been resolved. The Orthodox Church received autocephaly, Metropolitan Dionizy was moved outside Warsaw, and a new superior

37 See: The Protocols from the Meetings of the Provisional Governing Council, AAN, MAP, sign. 1044 and 1045.

38 AAN, MAP, sign. 1045, Protocol no. 21 of the Meeting of the Provisional Governing Council PAKP on March $16^{\text {th }}, 1949$. 
was elected. Basically, the Council implemented only the tasks assigned by the state authorities. Despite the attempts, they failed to reactivate the Orthodox Theology Studies at Warsaw University. They did not succeed in the attempt to create the jobs for Orthodox chaplains, who could meet the religious needs of Orthodox soldiers serving in the Polish Army and the inclusion of pastoral care of prisoners in prisons. The Council also failed to carry out the reorganization of diocesan structures in accordance with the requirements of autocephaly (the existence of at least 4 eparchies). Raised in November 1948, the concept of creating 3 of the dioceses (Warsaw-Bielsko, Łódź and Wrocław, and Białystok-Gdańsk), as well as the Bishop Michał's (Kiedrow) concept (dated January 1951) relating to the division into four dioceses (Warsaw, Białystok, Łódź, and Gdańsk), did not obtain the support of the state authorities. Finally, on September $7^{\text {th }}, 1951$, the Council of Bishops, now under the guidance of Metropolitan Makary, made a new diocese division, including four dioceses: Warsaw-Bielsko, Białystok-Gdańsk, Łódź-Poznań, and Wrocław-Szczecin ${ }^{39}$.

It is worth mentioning that due to personal crisis after the death of Metropolitan Tymoteusz (1962), the concept of "re-appointment to the life of the Provisional Governing Council PAKP" appeared among the clergy. The supporter of such a solution was Father E. Naumow. In a letter sent to the Office for Religious Affairs he stated that it was "the best form of government [...] it was fair and democratic body in relation to the clergy and faithful, loyal to its People's Government" ${ }^{40}$. In the changed political circumstances the state authorities, however, did not decide to repeat such a solution.

\section{REFERENCES:}

Antonova S.E. (2011). Patriarchal Orthodox Church of Bulgaria. [in:] The Encyclopedia of Eastern Orthodox Christianity. J.A. McGuckin (ed.). Hoboken: Blackwell Publishing Ltd.

Bendza M. (2006). Droga Kościoła prawosławnego w Polsce do autokefalii. Białystok: Wydawnictwo Uniwersytetu w Białymstoku.

39 Previously, the state authorities had rejected the Metropolitan Makary's concept of territorial division of the Metropolitan on dioceses: Warsaw-Bielsko, Białystok-Sokółka, Łódź and Wrocław, and Gdańsk-Szczecin; AWMP, Metropolitan Makary's Letter to the Office for Religious Affairs on August $16^{\text {th }}, 1951$, and September $7^{\text {th }}, 1951$.

40 AAN, UdSW, sign. 68/2, Priest E. Naumow's Letter to the Office for Religious Affairs on February $20^{\text {th }}, 1964$. 
Curanović A. (2010). Czynnik religijny w polityce zagranicznej Federacji Rosyjskiej. Warszawa: Wydawnictwo Uniwersytetu Warszawskiego.

Dudra S. (2010). Metropolita Dionizy (Waledyński) 1876-1960. Warszawa: Warszawska Metropolia Prawosławna.

Ławreszuk M. (2009). Prawosławie wobec tendencji nacjonalistycznych i etnofiletystycznych. Studium teologiczno-kanoniczne. Warszawa: Wydawnictwo Naukowe Semper.

Matwiejuk J. (2007). Kształtowanie się stanu prawnego Polskiego Autokefalicznego Kościoła Prawosławnego. „Elpis” 15-16. Białystok: Wydawnictwo Uniwersytetu w Białymstoku.

Michalak R. (2014). Polityka wyznaniowa państwa polskiego wobec mniejszości religijnych w latach 1945-1989. Zielona Góra: Oficyna Wydawnicza Uniwersytetu Zielonogórskiego.

Mironowicz A. (2005). Kościół prawosławny na ziemiach polskich w XIX i XX wieku. Białystok: Wydawnictwo Uniwersytetu w Białymstoku.

Parry K. (ed.) (2007). The Blackwell Companion to Eastern Christianity. Victoria: Blackwell Publishing.

Péter L. (1995). Church-State Relations and Civil Society in Hungary. A Historical Perspective. "Hungarian Studies" Vol. 10, No. 1.

Ramet P. (1984). Religion and Nationalism in Soviet and East European Politics. Durham: Duke University Press.

Sawicki. D. (2011). 50 lat temu odszedł do wieczności metropolita warszawski i całej Polski Makary. „Wiadomości Polskiego Autokefalicznego Kościoła Prawosławnego” 3. Warszawa: Warszawska Metropolia Prawosławna.

Suvarsky J. (1982). The 30 Anniversary of the Autocephaly of the Orthodox Church in Czechoslovakia. „Journal of the Moscow Patriarchate” 7.

Urban K. (1993). Kościót prawosławny w Polsce. Sprawa autokefalii z 1948 roku. „Cerkiewny Westnik" 10. Warszawa: Warszawska Metropolia Prawosławna.

Urban K. (1996). Kościót prawosławny w Polsce 1945-1970 (rys historyczny). Kraków: Zakład Wydawniczy NOMOS.

Urban K. (2007). Ksiadz Atanazy Semeniuk 1904-1996 (życie dtugie, trudne i ciekawe...). Warszawa: Warszawska Metropolia Prawosławna.

Znosko A. (1973). Prawosławne prawo kanoniczne. Warszawa: Chrześcijańska Akademia Teologiczna.

Zyzykin M. (1933). Autokefalia i zasady jej zastosowania. Warszawa: Instytut Wydawniczy „Bibljoteka Polska”.

Żerelik R. (1996). Zarys dziejów prawosławia na Śląsu po II wojnie światowej. [in:] Katedra Narodzenia Przenajświętszej Bogarodzicy we Wrocławiu. I. Rydzanicz (ed.). Wrocław: Oficyna Wydawnicza „Arboretum”. 